\title{
Four lichen species new for Russia
}

\author{
Gennadii Urbanavichus $^{1} \&$ Irina Urbanavichene ${ }^{2}$ \\ ${ }^{1}$ Institute of North Industrial Ecology Problems, Kola Science Centre RAS, Akademgorodok 14a, Apatity, \\ 184209 Murmansk Region, Russia. E-mail: g.urban@mail.ru \\ ${ }^{2}$ Komarov Botanical Institute RAS, Professor Popov Str. 2, 197376 St Petersburg, Russia. \\ E-mail: urbanavichene@gmail.com
}

\begin{abstract}
Four lichen species, Biatora chrysanthoides collected from Kostroma Region, Gyalidea minuta from Nizhnii Novgorod Region and Polyblastia borealis and Thelocarpon saxicola from Murmansk Region, are reported for the first time for Russia. Comments on their habitats, substrates, key anatomical features and world distribution are provided for each species.
\end{abstract}

Keywords: lichens, new records, Russia

\section{INTRODUCTION}

This article continues the series of publications on the new and important findings of lichens in different regions of Russia (Urbanavichus \& Urbanavichene, 2011, 2017, 2018; Urbanavichene \& Urbanavichus, 2014, 2019). Lichen investigations in 2019 allowed us to discover some species not previously reported for the lichen biota of Russia which currently consists of ca 4150 species (unpublished data of the first author).

\section{MATERIAL AND METHODS}

The paper is based mainly on specimens collected in 2019 by Gennadii Urbanavichus in Murmansk Region and Irina Urbanavichene in Kostroma and Nizhnii Novgorod Regions. The specimens were morphologically examined by standard microscopic techniques. Hand-cut sections and squash preparations were examined in water, a $10 \%$ aqueous solution of $\mathrm{KOH}$, and Lugol's solution. Measurements of well-developed free ascospores lying outside the asci were measured in water at $\times 1000$ magnification. Chromatography was performed by the authors according to the standard techniques of high performance thin-layer chromatography (HPTLC) in the Laboratory of Lichenology and Bryology of Komarov Botanical Institute of RAS, implementing solvent systems A and C (Orange et al., 2001). The specimens are deposited in the lichen herbaria of Komarov Botanical Institute RAS (LE) and of Institute of North Industrial Ecology Problems, Kola Science Centre RAS in Apatity (INEP).

\section{THE SPECIES}

Biatora CHRYSANTHOIDEs Printzen \& Tønsberg

Specimen examined: Russia, Kostroma Region, Kologriv District, Kologriv Forest State Nature Reserve, forest quarter no. 66, old growth spruce Picea abies forest on right bank of Vonyukh river, $58^{\circ} 48^{\prime} 17^{\prime \prime} \mathrm{N}, 43^{\circ} 56^{\prime} 44.1^{\prime \prime} \mathrm{E}$, alt. c. $190 \mathrm{~m}$, on bark of Picea, 16.05.2019, leg. I. Urbanavichene (LE L-15285). Kologrivian specimen is fertile: apothecia $0.2-0.4 \mathrm{~mm}$ diam., ascospores 8.4-10.2 × 3-3.3 $\mu \mathrm{m}$. Chemistry: gyrophoric acid in the thallus as well as in apothecia (HPTLC). Spot tests: thallus and soralia C+ red, apothecia C+ fleetingly rose-reddish.

The species is superficially similar to B. chrysantha (Zahlbr.) Printzen, which also has a sorediate thallus containing gyrophoric acid. In contrast to $B$. chrysantha, cross sections of apothecia react $\mathrm{C}+$ red in $B$. chrysanthoides (Printzen \& Tønsberg, 2003). Biatora chrysanthoides is distinguished by considerably smaller ascospores (in B. chrysantha ascospores (10-)11.9-15.6(19.5) $\times(3-) 3.8-5.9(-7.5) \mu \mathrm{m})$, and distinctly smaller apothecia (in $B$. chrysantha apothecia 0.4-0.7(-1.1) mm diam.) (Printzen, 1995). Biatora chrysanthoides has been previously known from Canada, Norway, and the United States (Printzen \& Tønsberg 2003), and recently reported from Sweden (Ekman et al., 2019).

Gyalidea minuta van den Boom \& Vězda (Fig. 1)

Specimen examined: Russia, Nizhnii Novgorod Region, Bor District, Kerzhenskii State Nature Reserve, forest quarter no. 52, floodplain alder Alnus glutinosa forest with Picea sp. and Populus tremula near the nameless stream, $56^{\circ} 32^{\prime} 10.2^{\prime \prime} \mathrm{N}, 4^{\circ} 54^{\prime} 23.4^{\prime \prime} \mathrm{E}$, alt. c. $100 \mathrm{~m}$, on the trunk of a very shaded old Alnus glutinosa, 03.05.2019, leg. I. Urbanavichene (LE L-15284). 


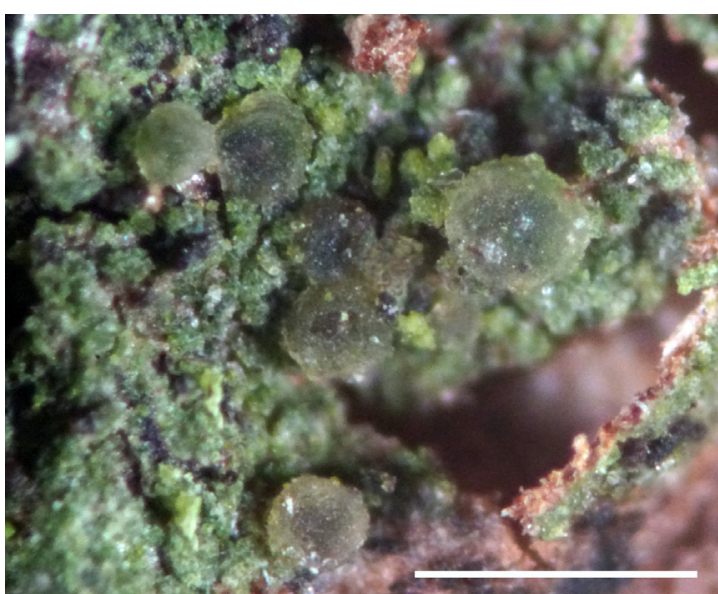

Fig. 1. Apothecia of Gyalidea minuta. Scale bar $=0.5 \mathrm{~mm}$.

Gyalidea minuta is characterized by its small (c. 125-250 $\mu \mathrm{m}$ diam. in the studied specimen, 200-400 $\mu \mathrm{m}$ diam. in western-central European specimens) and pale yellowish-brownish apothecia which are clearly constricted at the base, and the habitat preference, tree bark. The ascospores are submuriform and short: 10.2-15.3 $\mu \mathrm{m}$ in the studied specimen (still within the range of measures of other European specimens, (9.5-)10-17(-20) $\mu \mathrm{m})$ (Kubiak \& Maliek, 2012). Owing to its very small size, the species is easily overlooked, even under the dissecting microscope. Gyalidea minuta has been previously reported from five countries: Portugal (van den Boom \& Vězda, 1995), France and Belgium (Sparrius et al., 2002), and Poland and Czech Republic (Kubiak \& Malíček, 2012). The current finding in the center of the East European Plain significantly expands the known distribution of this taxon (Fig. 2). The disjunction of c. 1600 $\mathrm{km}$ between Northern Poland and Kerzhenskii Reserve is hardly real since the species certainly has been overlooked in the intervening area.

Because of their very small size, inconspicuous appearance and short life cycle, members of the genus Gyalidea are easily overlooked in the field. Five species of this genus have been noted in Russia, many of which are extremely rare with only single localities: G. asteriscus (Anzi) Aptroot \& Lücking, G. diaphana (Nyl.) Vězda, G. fritzei (Stein) Vězda, G. lecideopsis (A. Massal.) Lettau and G. scutellaris (Bagl. \& Carestia) Lettau (Urbanavichus, 2010; Melechin, 2016). All these

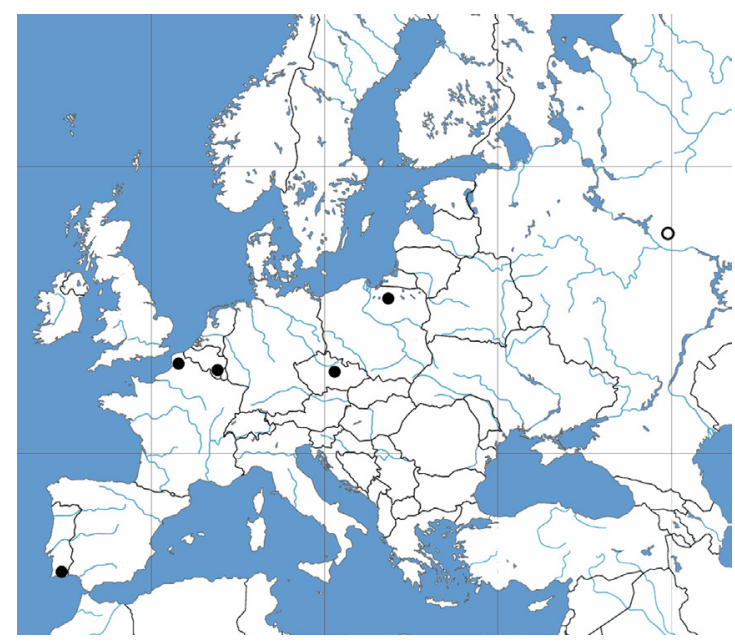

Fig. 2. Known distribution of Gyalidea minuta according to Kubiak \& Malíček (2012), amended. The locality in Kerzhenskii Reserve is marked with .

species grow on soil, rocks, mosses or on plant debris. Gyalidea minuta is the first corticolous species of the genus in Russia.

\section{Polyblastia BOREalis Savić \& Tibell}

Specimen examined: Russia, Murmansk Region, Lovozero District, c. $100 \mathrm{~km} \mathrm{SE}$ of Lovozero settlement, West Keivy Mountains, c. $5.5 \mathrm{~km} \mathrm{~S}$ of Parusnaya Mt., Nature Monument "Amazonites of Parusnaya Mt.", birch forest-tundra belt, old geological pit in amazonite deposit, $67^{\circ} 35^{\prime} 23^{\prime \prime} \mathrm{N}, 37^{\circ} 09^{\prime} 09^{\prime \prime} \mathrm{E}$, alt. c. $230 \mathrm{~m}$, on amazonite pegmatite rock, 29.07.2019, leg. E. N. Kozlov (INEP 0393).

The species is recognized by pale areolate thallus, the rather small to medium sized, emerging perithecia which have an adpressed involucrellum and pale excipulum base, and the hyaline, medium-sized spores with 5-6 transversal and 2-3 longitudinal septa. It is similar to $P$. hyperborea Th. Fr., which differs in having a thick involucrellum that extends horizontally from the ostiolum, and larger ascospores (Savić \& Tibell, 2012). The species was described from Torne Lappmark in Northern Sweden and is widely distributed in Central and Northern Fennoscandia (Norway, Sweden, Finland), and further known from Iceland, Bjørnøya and Svalbard (Tibell \& Tibell, 2017). The current locality of $P$. borealis in the Kola Peninsula is the easternmost, but it is quite reasonable that the species is distributed also in Northeastern Fennoscandia. 
Thelocarpon saxicola (Zahlbr.) H. Magn.

Specimen examined: Russia, Murmansk Region, Pechenga district, Nature Park "Korablekk", pine forest near NE end of Nilijärvi Lake, 69¹4'37.3”N, $29^{\circ} 26^{\prime} 49.3$ " E, alt. c. $125 \mathrm{~m}$, on siliceous rocks with Ionaspis lacustris (With.) Lutzoni and Verrucaria latebrosa Körb. on the left bank of a nameless stream, 02.09.2019, leg. G. Urbanavichus (INEP 0324).

Thelocarpon saxicola is distinguished from other members of the genus by its small, yellow-pruinose, globose perithecioid ascomata (120-150 $\mu \mathrm{m}$ diam.), non-amyloid asci and hymenial gel, the lack of paraphyses, and its saxicolous habitat. It is not lichenized (algal sheath absent), but free-living coccoid green algae are associated at the base of ascomata. An extremely rare minuscule lichen, probably overlooked and could be more widespread, previously known from some European countries - Austria, Germany, Great Britain, Luxembourg, Poland, Spain, Sweden (Kozik, 1973; Cezanne et al., 2008; Eichler et al., 2010; Nordin et al., 2011; Orange, 2013). Its closest known locality is in Västergötland, Sweden (Nordin et al., 2011).

\section{ACKNOWLEDGEMENTS}

The work of G. P. Urbanavichus was carried out within the framework of the State Research Program of the Kola Science Centre of RAS (no. AAAA-A18-118021490070-5). The work of I. N. Urbanavichene was carried out within the framework of the State Research Program of the Komarov Botanical Institute of RAS (no. AAAA-A19-119020690077-4). We are grateful to an anonymous reviewer and Tiina Randlane (University of Tartu) for valuable corrections.

\section{REFERENCES}

Cezanne, R., Eichler, M., Hohmann, M.-L. \& Wirth, V. 2008. Die Flechten des Odenwaldes. Andrias 17: $1-520$.

Eichler, M., Cezanne, R., Diederich, P., Ertz, D., Van den Broeck, D., Van den Boom, P. \& Sérusiaux, E. 2010. New or interesting lichens and lichenicolous fungi from Belgium, Luxembourg and northern France. XIII. Bulletin de la Société des naturalistes luxembourgeois 111: 33-46.

Ekman, S., Svensson, M., Westberg, M. \& Zamora, J. C. 2019. Additions to the lichen flora of Fennoscandia III. Graphis Scripta 31(5): 34-46.

Kozik, R. 1973. Thelocarpon saxicola (A. Zahlbr.) H. Magn. - a new species of lichens in the Polish flora. Fragmenta Floristica et Geobotanica 19: 339-341.

Kubiak, D. \& Malíček, J. 2012. Gyalidea minuta in Central Europe - new data on its distribution, ecology, and morphological variation. Mycotaxon 119: 11-16. https://doi.org/10.5248/119.11

Lendemer, J. 2013. A monograph of the crustose members of the genus Lepraria Ach. s. str. (Stereocaulaceae, Lichenized Ascomycetes) in North America north of Mexico. Opuscula Philolichenum 11: 27-141.

McMullin, R. T. 2019. New and interesting Canadian lichens and allied fungi II: Reports from British Columbia, New Brunswick, Nova Scotia, Nunavut, Prince Edward Island, Ontario, and Quebec. Opuscula Philolichenum 18: 396-419.

Melechin, A. 2016. Gyalecta biformis and Gyalidea diaphana new to Russia. Graphis Scripta 28: 11-13.

Nordin, A., Moberg, R., Tonsberg, T., Vitikainen, O., Dalsatt, A., Myrdal, M., Snitting, D. \& Ekman, S. 2011. Santesson's Checklist of Fennoscandian Lichen-forming and Lichenicolous Fungi. Ver. April 29, 2011. http://130.238.83.220/santesson/ home.php (23 December 2019).

Orange, A. 2013. British and other pyrenocarpous lichens. Department of Biodiversity and Systematic Biology, National Museum of Wales, Cardiff.

Orange, A., James, P. W. \& White, F. J. 2001. Microchemical methods for the identification of lichens. British Lichen Society, London.

Printzen, C. 1995. Die Flechtengattung Biatora in Europa. Bibliotheca Lichenologica 60: 1-275.

Printzen, C. \& Tønsberg, T. 2003. Four new species and three new apothecial pigments of Biatora. Bibliotheca Lichenologica 86: 133-145.

Pykälä, J., Lendemer, J. C., Malíček, J., Haughland, D. L. \& Huhtinen, S. 2017. Interesting lichens found during the IAL8 pre-excursion in the southwestern archipelago of Finland 2016. Graphis Scripta 29(1-2): 57-64.

Savić, S. \& Tibell, L. 2012. Polyblastia in Northern Europe and the adjacent Arctic. Symbolae Botanicae Upsalienses 36(1): 1-69.

Slaviková-Bayerová, Š. \& Orange, A. 2006. Three new species of Lepraria (Ascomycota, Stereocaulaceae) containing fatty acids and atranorin. Lichenologist 38(6): 503-513. https://doi.org/10.1017/ S0024282906006177

Sparrius, L. B., Diederich, P., Signoret, J. \& Sérusiaux, E. 2002. The lichen flora of the Boulonnais (France, Pas-de-Calais). Belgian Journal of Botany 135: 50-75.

Strasser, E. A., Hafellner, J., Stešević, D., Geci, F. \& Mayrhofer, H. 2015. Lichenized and lichenicolous fungi from the Albanian Alps (Kosovo, Montenegro). Herzogia 28: 520-544. https://doi. org/10.13158/heia.28.2.2015.520

Tibell, S. \& Tibell, L. 2017. Polyblastia. Nordic Lichen Flora 6: 35-51. 
Urbanavichene, I. \& Urbanavichus, G. 2014. Bacidia pycnidiata discovered in European Russia. Folia Cryptogamica Estonica 51: 109-112. https://doi. org/ 10.12697/fce.2014.51.12

Urbanavichene, I. \& Urbanavichus, G. 2019. New records of lichens and allied fungi from the Kostroma Region, Russia. Folia Cryptogamica Estonica 56: 53-62. https://doi.org/10.12697/ fce.2019.56.06

Urbanavichus, G. P. 2010. A checklist of the lichen flora of Russia. Nauka, St-Petersburg.

Urbanavichus, G. \& Urbanavichene, I. 2011. New records of lichens and lichenicolous fungi from the Ural Mountains, Russia. Folia Cryptogamica Estonica 48: 119-124.
Urbanavichus, G. \& Urbanavichene, I. 2017. New records and noteworthy lichens and lichenicolous fungi from Pasvik Reserve, Murmansk Region, Russia. Folia Cryptogamica Estonica 54: 31-36. https://doi.org/10.12697/fce.2017.54.06

Urbanavichus, G. \& Urbanavichene, I. 2018. New records of lichens and allied fungi from Lapponia petsamoënsis, Murmansk Region, Russia. Folia Cryptogamica Estonica 55: 1-5. https:/ / doi. org/10.12697/fce.2018.55.01

Van den Boom, P. P. G. \& Vězda, A. 1995. A new species and a new variety of the lichen genus Gyalidea from western Europe. Mycotaxon 54: 421-426.

Wirth, V., Hauck, M. \& Schultz, M. 2013. Die Flechten Deutschlands. Ulmer, Stuttgart. 